\title{
Varietal performance of modern transplant Aman rice subjected to level of nitrogen application
}

\author{
M. S. Islam, S. K. Paul ${ }^{*}$ and M. A. R. Sarkar \\ Department of Agronomy, Bangladesh Agricultural University, Mymensingh-2202, Bangladesh, *E-mail: \\ skpaull@gmail.com
}

\begin{abstract}
An experiment was carried out at the Agronomy Field Laboratory, Bangladesh Agricultural University, Mymensingh during June to December 2012 with a view to finding out the effect of variety and nitrogen fertilizer application on the growth and yield of transplant Aman rice. The experiment comprised four varieties viz. BRRI dhan33, BRRI dhan34, BRRI dhan39 and BRRI dhan46, and four levels of nitrogen viz. control (no urea), prilled urea (50 kg N ha ${ }^{-1}$ ), one pellet $(0.9 \mathrm{~g})$ of USG/4 hills of two adjacent rows ( $\cong 30 \mathrm{~kg} \mathrm{~N} \mathrm{ha}^{-1}$ ) was applied at 10 DAT and two pellets of USG ( $0.9 \mathrm{~g}$ each) one applied at 10 DAT and the other at 45 DAT/4 hills of two adjacent rows ( $\left.\cong 60 \mathrm{~kg} \mathrm{~N} \mathrm{ha}^{-1}\right)$. The experiment was laid out in a randomized complete block design with three replications. Results of the experiment showed that variety and level of nitrogen application had significant effect on yield attributes and yield of transplant Aman rice. At maturity the tallest plant $(122.60 \mathrm{~cm})$ and the highest number total tillers hill ${ }^{-1}(12.72)$ were observed in two pellets of USG/4 hills providing $60 \mathrm{~kg} \mathrm{~N} \mathrm{ha}^{-1}$. The highest number of tillers hill ${ }^{-1}(10.08)$ was obtained from BRRI dhan34 and the lowest one (9.88) from BRRI dhan33. The highest grain yield was obtained from BRRI dhan46 (4.56 $t$ $\left.\mathrm{ha}^{-1}\right)$ and the lowest one $\left(3.27 \mathrm{t} \mathrm{ha}^{-1}\right)$ was obtained from BRRI dhan34. The interaction reveals that the highest grain yield $\left(5.61 \mathrm{t} \mathrm{ha}^{-1}\right)$ was obtained from the treatment combination of BRRI dhan46 with two pellets of USG (0.9g each) applied one at 10 DAT and the other at 45 DAT.
\end{abstract}

Keywords: Transplant Aman rice, Variety, Nitrogen, Prilled urea and USG

\section{Introduction}

Rice is the staple food crop of the people of Bangladesh where it is extensively grown in Aus, Aman and Boro seasons. Aman rice covers the largest area of 5.64 million hectares with a production of 12.70 million tons of rice among three distinct growing in Bangladesh (BBS, 2011). With ever increasing population, demand for rice will continue to increase. In this endeavour, in addition to high yielding rice varieties, efficient use of nutrients play an important role. Among the major plant nutrients, nitrogen is most important for augmenting rice yield. Depletion of soil fertility has been identified as a major constraint for higher crop yield. Among the various factors responsible for increasing yield and quality of rice, fertilizer management is of paramount importance (Novoa and Loomis, 1981). Use of fertilizer is an essential component of modern farming with about $50 \%$ of the world crop production (Prodhan, 1992). For rice production, nitrogen is the key nutrient required in the largest quantities while urea is the principal nitrogenous fertilizer. However, $\mathrm{N}$ from urea is subject to considerable losses to the atmosphere and run off water in the rice ecosystem, especially where urea is broadcast on standing water. On a global level, more than 55 percent of the $\mathrm{N}$ applied through urea fertilizer to irrigated rice is not taken up and eventually liable to loss.

In Bangladesh, prilled urea (PU) conventionally applied by farmers is very inefficiently used in transplant Aman rice largely because of serious losses (up to $60 \%$ of applied $\mathrm{N}$ ) via $\mathrm{NH}_{3}$ volatilization, denitrification, leaching, and/or run off. In order to minimize $\mathrm{N}$ loss, especially loss due to denitrification, use of USG instead of prilled urea is very beneficial for transplant Aman rice. USG can be prepared by melt-type processes (pan granulation, falling curtain, and fluid bed) and briquetting (a special type of compaction). Placement of USG can be done efficiently by hand near the center of each four rice hills to a 7-10 cm soil depth. The deep-placed USG-N is well protected from various $\mathrm{N}$ loss mechanisms (except leaching) at the placement sites in soils and the spatial ammonium concentration gradients help to improve its plant availability. Depending on agro-climate and $\mathrm{N}$ rates used, in general deep-placed USG can help to provide a saving of urea fertilizer of up to $65 \%$ with an average of $33 \%$ and can help to increase grain yields up to $50 \%$ with an average of $15 \%$ to $20 \%$ over that with the same amount of split-applied $\mathrm{N}$ as prilled urea (Fatema-Tuz-Zohra et al. 2013). Thus, this practice is efficient in agronomic point of view. It is also environmentally safe. Based on the above information, the study was undertaken to investigate the performance of transplant rice varieties under various levels of nitrogen application. 


\section{Materials and Methods}

The experiment was conducted at the Agronomy Field laboratory, Bangladesh Agricultural University, Mymensingh during July to December 2012. The experimental site belongs to the Sonatola Soil Series of Old Brahmaputa Floodplain (AEZ 9) having non calcareous dark grey floodplain soil. The land was medium high with sandy loam texture having $\mathrm{pH}$ 5.9-6.5. The experiment consisted of four varieties viz. BRRI dhan33, BRRI dhan34, BRRI dhan39 and BRRI dhan46; and four levels of nitrogen viz. control (no urea), prilled urea $\left(50 \mathrm{~kg} \mathrm{~N}^{-1}\right)$, one pellet $(0.9 \mathrm{~g})$ of USG/4 hills of two adjacent rows $\left(\cong 30 \mathrm{~kg} \mathrm{~N} \mathrm{ha}^{-1}\right.$ ) was applied at 10 DAT and two pellets of USG $(0.9 \mathrm{~g}$ each) one applied at 10 DAT and the other at 45 DAT/4 hills of two adjacent rows ( $\cong 60 \mathrm{~kg} \mathrm{~N} \mathrm{ha}^{-1}$ ). The experiment was laid out in a randomized complete block design with three replications. The size of unit plot was $4.0 \mathrm{~m} \times 2.5 \mathrm{~m}$. Spacing of $1 \mathrm{~m}$ and $0.75 \mathrm{~m}$ were maintained in between the replications and unit plot, respectively. Fertilizers were applied to the plots at the rate of $90,60,40$ and $10 \mathrm{~kg} \mathrm{ha}^{-1}$ of $\mathrm{P}_{2} \mathrm{O}_{5}, \mathrm{~K}_{2} \mathrm{O}, \mathrm{S}$ and $\mathrm{Zn}$ through triple super phosphate, muriate of potash, gypsum and zinc sulphate at the time of final land preparation. Prilled urea was applied at the rate of $50 \mathrm{~kg} \mathrm{~N} \mathrm{ha}^{-1}$ in three installments at 15, 30 and 45 DAT. As per experimental specification USG were placed manually (depth $6-8 \mathrm{~cm}$ ) at the centre of four hills of two adjacent rows at 10 days after transplanting (DAT). In case of twice, USG was placed at 10 DAT and 45 DAT. Five hills were selected from each plots excluding boarder rows and central area $(1.0 \mathrm{~m} \times 1.0 \mathrm{~m})$. The crop was harvested at different times according to varietal maturity. Harvesting was done from central area of $1 \mathrm{~m}^{2}$ to record the yields of grain and straw. The harvested crop was then threshed, cleaned and sun dried to record the grain yield plot $^{-1}$, which was finally converted to $t^{-1} a^{-1}$ at $14 \%$ moisture basis. The recorded data were statistically analyzed using the "Analysis of Variance" technique and the differences among treatment means were adjudged by Duncan's New Multiple Range Test (Gomez and Gomez, 1984).

\section{Results and Discussion}

\section{Varietal performance}

The crop characters, yield components and yield of transplant Aman rice were significantly influenced by variety. The highest plant height $(124.30 \mathrm{~cm})$ was recorded from BRRI dhan34 followed by BRRI dhan39, BRRI dhan46 and the lowest one (100.96) was found in BRRI dhan33 (Table 1). These differences are mostly due to the genetic variation among the varieties. These results are in agreement with that of Tyeb et al. (2013) who recorded variable plant height among varieties. The highest number of total tillers hill ${ }^{-1}$ (10.08) was produced by BRRI dhan34, which was statistically identical to BRRI dhan46 (9.92) and BRRI dhan33 (9.88) while the lowest one was recorded from BRRI dhan39 (8.92). Variable effect on number of total tillers hill $^{-1}$ was also reported by Nuruzzaman et al. (2000) who noticed that number of total tillers hill ${ }^{-}$ 1 differed among the varieties. The variation in number of total tillers hill ${ }^{-1}$ as assessed might be due to varietal characters. The highest number of effective tillers (8.31) hill ${ }^{-1}$ was found in BRRI dhan34, which was as good as BRRI dhan46 (8.19) and the lowest one (6.80) was found in BRRI dhan39. The probable reason of the differences in producing effective tillers hill ${ }^{-1}$ is the genetic make up of the variety. These findings corroborate with those reported by Bhowmick and Nayak (2000) who stated that effective tillers hill $^{-1}$ varied with variety. The highest number of grains panicle ${ }^{-1}(146.49)$ was produced by BRRI dhan34 which was statistically identical to BRRI dhan46 (144.48) and the lowest one (130.80) was recorded in BRRI dhan33. Variable number of grains panicle ${ }^{-1}$ among varieties was reported by Bhowmick and Nayak (2000) and Niu et al. (2001). Varietal differences regarding the number of grains panicle ${ }^{-1}$ might be due to their differences in genetic constitution. BRRI dhan33 produced the highest number of sterile spikelets panicle $^{-1}(22.24)$ and the lowest number of sterile spikelets panicle ${ }^{-1}(20.13)$ was produced by BRRI dhan39. Chowdhury et al. (1993) also found the varietal differences on number of sterile spikelets panicle ${ }^{-1}$. The highest grain yield $\left(4.56 \mathrm{t} \mathrm{ha}^{-1}\right)$ was recorded in BRRI dhan46 followed by BRRI dhan39 $\left(4.38 \mathrm{t} \mathrm{ha}^{-1}\right)$, BRRI dhan33 $\left(4.17 \mathrm{t} \mathrm{ha}^{-1}\right)$ and the lowest grain yield $\left(3.27 \mathrm{t} \mathrm{ha}^{-1}\right)$ was recorded from BRRI dhan34. Grain yield differences might be due to the production potential of varieties for genetic characteristics. Grain yield differed due to varietal differences was also reported elsewhere Tyeb et al. (2013). The highest straw yield $\left(6.43 \mathrm{t} \mathrm{ha}^{-1}\right)$ was produced by BRRI dhan34 and the lowest $\left(5.65 \mathrm{t} \mathrm{ha}^{-1}\right)$ was produced by BRRI dhan33. Hossain et al. (1995) reported variable straw yields among the varieties. 
The highest biological yield (11.33 tha $\left.{ }^{-1}\right)$ was obtained from BRRI dhan46 and the lowest one $\left(9.88 \mathrm{t} \mathrm{ha}^{-1}\right)$ was obtained from BRRI dhan34 (Table 1). Plant variety positively influenced grain yield and straw yield which in turn increased the biological yield. The highest harvest index $(44.52 \%)$ was recorded in BRRI dhan46 and the lowest harvest index (42.14\%) was observed in BRRI dhan34 (Table 1).

Table 1. Effect of variety on crop characters, yield components and yield of transplant Aman rice

\begin{tabular}{|c|c|c|c|c|c|c|c|c|c|c|c|}
\hline Variety & \begin{tabular}{|c|} 
Plant height \\
$(\mathrm{cm})$
\end{tabular} & $\begin{array}{c}\text { Total } \\
\text { tillers } \\
\text { hill-1(no.) }^{-1}\end{array}$ & $\begin{array}{c}\text { Effective } \\
\text { tillers hill-1-1 } \\
\text { (no.) }\end{array}$ & $\begin{array}{c}\text { Non-effective } \\
\text { tillers hill-1-1 } \\
\text { (no.) }\end{array}$ & $\begin{array}{c}\text { Grains } \\
\text { penicle-1 }^{-1} \\
\text { (no.) }\end{array}$ & $\begin{array}{c}\text { Sterile } \\
\text { spikelets } \\
\text { penicle-1 (no.) }^{-1}\end{array}$ & $\begin{array}{c}\begin{array}{c}1000- \\
\text { grain } \\
\text { weight }(\mathrm{g})\end{array} \\
\end{array}$ & $\begin{array}{c}\text { Grain } \\
\text { yield } \\
(\mathrm{t} \mathrm{ha-1})\end{array}$ & $\begin{array}{c}\text { Straw } \\
\text { yield } \\
\left(\mathrm{t} \mathrm{ha}^{-1}\right)\end{array}$ & \begin{tabular}{|c|}
$\begin{array}{c}\text { Biological } \\
\text { yield } \\
\left(\mathrm{t} \mathrm{ha}^{-1}\right)\end{array}$ \\
\end{tabular} & $\begin{array}{c}\text { Harvest } \\
\text { Index } \\
(\%) \\
\end{array}$ \\
\hline BRRI dhan33 & $100.96 \mathrm{~d}$ & $9.88 \mathrm{a}$ & $7.55 b$ & $2.33 a$ & $130.80 \mathrm{c}$ & $22.24 a$ & 23.13 & $4.17 \mathrm{~b}$ & $5.65 b$ & $11.27 a$ & $42.58 b$ \\
\hline BRRI dhan34 & $124.30 \mathrm{a}$ & $10.08 \mathrm{a}$ & $8.31 a$ & $1.78 \mathrm{~b}$ & $146.49 a$ & $21.17 a b$ & 22.86 & $3.27 \mathrm{c}$ & $6.43 a$ & $9.88 \mathrm{c}$ & $42.14 b$ \\
\hline BRRI dhan39 & $111.07 \mathrm{~b}$ & $8.92 b$ & $6.80 \mathrm{c}$ & $2.12 a b$ & $140.70 \mathrm{~b}$ & $20.13 b$ & 23.39 & $4.38 \mathrm{~b}$ & $6.24 a$ & $10.78 b$ & $42.23 b$ \\
\hline BRRI dhan46 & $106.83 c$ & $9.92 a$ & $8.19 a$ & $1.73 b$ & $144.48 \mathrm{a}$ & $20.48 b$ & 23.35 & $4.56 \mathrm{a}$ & $6.29 a$ & $11.33 a$ & $44.52 a$ \\
\hline CV (\%) & 4.03 & 7.14 & 9.19 & 12.82 & 3.40 & 8.32 & 3.47 & 4.58 & 4.20 & 3.65 & 3.5 \\
\hline Level of sig. & ** & ** & ** & ** & ** & ** & NS & ** & ** & ** & ** \\
\hline
\end{tabular}

In a column, figures with same letter or without letter do not differ significantly whereas figures with dissimilar letters differ significantly as per DMRT, NS= Not significant, ${ }^{* *}=$ Significant at $1 \%$ level of probability.

\section{Effect of nitrogen fertilizer application}

Application of various levels of nitrogen significantly affected crop characters, yield components and yield of transplant Aman rice. The highest plant height $(113.06 \mathrm{~cm}$ ) was recorded when 2 pellets of USG/4 hills providing $60 \mathrm{~kg} \mathrm{~N} \mathrm{ha}^{-1}$ was applied and the lowest one $(108.53 \mathrm{~cm}$ ) was recorded from control (Table 2). Increased plant height due to increased level of USG might be associated with stimulating effect of nitrogen on various physiological processes including cell division and cell elongation of the plant. In general, plant height increased with the increasing level of nitrogen as USG. These results explicitly confirm the similar results obtained by Alam (2002) who recorded a positive effect of USG level on plant height. The highest number of total tillers hill ${ }^{-1}(12.09)$ was produced by 2 pellets of USG/4 hills providing $60 \mathrm{~kg} \mathrm{~N} \mathrm{ha}^{-1}$ and the lowest (6.18) by the control treatment (Table 2). Total tillers hill ${ }^{-1}$ was positively correlated with applied level of nitrogen as reported by BRRI (1991). The highest number of effective tillers hill ${ }^{-1}$ (10.03) was obtained from 2 pellets of USG/4 hills and the lowest one (3.68) was recorded in the control treatment (Table 2). Number of effective tillers hill ${ }^{-1}$ was different due to different levels of nitrogen application. Adequacy of nitrogen as USG probably favoured the cellular activities during panicle formation and development which led to increased number of effective tillers

hill $^{-1}$. Singh and Singh (1986) also expressed similar views. The highest number of grains panicle ${ }^{-1}$ (155.25) was produced when the level of USG was two pellets providing $60 \mathrm{~kg} \mathrm{ha}^{-1}$ and the lowest number of grains panicle ${ }^{-1}$ (133.83) was obtained from the control treatment (Table 2). The highest number of sterile spikelets panicle ${ }^{-1}$ (27.92) was obtained in control treatment and the lowest number of sterile spikelets panicle ${ }^{-1}(14.31)$ was recorded in the treatment with two pellets of USG/4 hills providing $60 \mathrm{~kg} \mathrm{~N}$ $\mathrm{ha}^{-1}$ (Table 2). The highest grain yield $\left(5.24 \mathrm{t} \mathrm{ha}^{-1}\right)$ was produced when the crop was fertilized with two pellets of USG/4 hills providing $60 \mathrm{~kg} \mathrm{~N} \mathrm{ha}^{-1}$ followed by one pellet of USG/4 hills, which was statistically identical to prilled urea providing $50 \mathrm{~kg} \mathrm{~N} \mathrm{ha}^{-1}$ and the lowest grain yield $\left(3.11 \mathrm{t} \mathrm{ha}^{-1}\right)$ was recorded in the control treatment (Table 2). Improvement of yield components such as number of effective tillers hill ${ }^{-1}$ and number of grains panicle ${ }^{-1}$ in these treatments ultimately resulted in high yield of grains. The highest straw yield $\left(6.93 \mathrm{tha}^{-1}\right)$ was produced by two pellets of USG/4 hills providing $60 \mathrm{~kg} \mathrm{~N} \mathrm{ha}^{-1}$ and he lowest one $\left(5.55 \mathrm{t} \mathrm{ha}^{-1}\right)$ was recorded from prilled urea providing $50 \mathrm{~kg} \mathrm{~N} \mathrm{ha}^{-1}$ (Table 2). Nitrogen influenced vegetative growth in terms of plant height and number of total tillers hill ${ }^{-1}$, which resulted in the highest straw yield. The highest biological yield $\left(12.13 \mathrm{t} \mathrm{ha}^{-1}\right)$ was obtained from two pellets of USG/4 hills providing $60 \mathrm{~kg} \mathrm{~N} \mathrm{ha}^{-1}$ and the lowest biological yield $\left(9.64 \mathrm{t} \mathrm{ha}^{-1}\right)$ was obtained from controlled treatment (Table 2). The highest harvest index (42.91\%) was recorded in two pellets of USG/4 hills providing $60 \mathrm{~kg}$ $\mathrm{N} \mathrm{ha}{ }^{-1}$ and the lowest harvest index $(41.71 \%)$ was found in the control treatment (Table 2$)$. 
Table 2. Effect of nitrogen level on crop characters, yield components and yield of transplant Aman rice

\begin{tabular}{|c|c|c|c|c|c|c|c|c|c|c|c|c|}
\hline $\begin{array}{c}\text { Nitrogen } \\
\text { level } \\
\left(\mathrm{kg} \mathrm{ha}^{-1}\right)\end{array}$ & $\begin{array}{l}\text { Plant } \\
\text { height } \\
(\mathrm{cm})\end{array}$ & \begin{tabular}{|c} 
Total \\
tillers hill-1 \\
(no.)
\end{tabular} & \begin{tabular}{|c|} 
Effective \\
tillers hill-11 \\
(no.)
\end{tabular} & $\begin{array}{c}\text { Non-effective } \\
\text { tillers hill-1 } \\
\text { (no.) }\end{array}$ & $\begin{array}{l}\text { Panicle } \\
\text { length } \\
(\mathrm{cm})\end{array}$ & $\begin{array}{l}\text { Grains } \\
\text { panicle-1 } \\
\text { (no.) }\end{array}$ & \begin{tabular}{|c} 
No. of sterile \\
spikelets \\
(no.)
\end{tabular} & $\begin{array}{c}1000- \\
\text { grain } \\
\text { weight }(\mathrm{g})\end{array}$ & $\begin{array}{c}\text { Grain } \\
\text { yield } \\
\left(\mathrm{t} \mathrm{ha}^{-1}\right)\end{array}$ & $\begin{array}{l}\text { Straw } \\
\text { yield ( } t \\
\text { ha-1) }^{-1}\end{array}$ & $\begin{array}{c}\text { Biological } \\
\text { yield } \\
\left(\mathrm{t} \mathrm{ha}^{-1}\right)\end{array}$ & $\begin{array}{c}\text { Harvest } \\
\text { index } \\
(\%)\end{array}$ \\
\hline $\mathrm{N}_{0}$ & $108.53 c$ & $6.18 \mathrm{~d}$ & $3.68 d$ & $2.50 a$ & 21.78 & $133.83 c$ & $27.92 a$ & 23.48 & $3.11 \mathrm{c}$ & $6.05 b$ & $10.74 \mathrm{~b}$ & $41.71 \mathrm{c}$ \\
\hline $\mathrm{N}_{1}$ & $110.32 \mathrm{bc}$ & $9.60 \mathrm{c}$ & $7.07 c$ & $2.52 a$ & 20.47 & $136.11 \mathrm{bc}$ & $22.47 \mathrm{~b}$ & 23.08 & $4.45 \mathrm{~b}$ & $5.55 c$ & $9.64 c$ & $42.18 b$ \\
\hline $\mathrm{N}_{2}$ & 111.24ab & $10.94 b$ & $9.46 \mathrm{~b}$ & $1.48 \mathrm{~b}$ & 21.31 & \begin{tabular}{|l|}
$137.28 b$ \\
\end{tabular} & $19.33 c$ & 23.30 & $4.58 \mathrm{~b}$ & $6.07 \mathrm{~b}$ & $10.59 \mathrm{~b}$ & $42.68 \mathrm{~b}$ \\
\hline $\mathrm{N}_{3}$ & $113.06 a$ & $12.09 a$ & $10.63 a$ & $1.47 \mathrm{~b}$ & 21.02 & $155.25 a$ & $14.31 \mathrm{~d}$ & 23.00 & $5.24 a$ & $6.93 a$ & $12.13 a$ & 42.91ab \\
\hline CV(\%) & 4.03 & 7.14 & 9.19 & 12.82 & 6.23 & 3.4 & 8.32 & 3.47 & 4.58 & 4.2 & 3.65 & 3.5 \\
\hline Level of sig. & ** & ** & ** & $* *$ & NS & $* *$ & ** & NS & ** & ** & ** & $* *$ \\
\hline
\end{tabular}

In a column, figures with same letter or without letter do not differ significantly whereas figures with dissimilar letters differ significantly as per DMRT, NS= Not significant, ${ }^{* *}=$ Significant at $1 \%$ level of probability.

$\mathrm{N}_{0}=$ Control, $\mathrm{N}_{1}=$ Prilled urea $\left(50 \mathrm{~kg} \mathrm{~N} \mathrm{ha}^{-1}\right), \mathrm{N}_{2}=$ One pellet $(0.9 \mathrm{~g})$ of USG $/ 4$ hills of two adjacent rows [applied at 10 DAT], $\mathrm{N}_{3}=$ Two pellets $(0.9 \mathrm{~g}$ each) of USG $/ 4$ hills of two adjacent rows [One pellet was applied at 10 DAT and another one at 45 DAT

\section{Effect of interaction of variety and nitrogen fertilizer application}

Different plant characters, yield components and yield of transplant Aman rice was significantly influenced by the interaction between variety and level of nitrogen. The highest plant height $(125.68 \mathrm{~cm})$ was recorded from the treatment combination of BRRI dhan34 with 2 pellets of USG/4 hills providing $60 \mathrm{~kg} \mathrm{~N}$ $\mathrm{ha}^{-1}$. The shortest plant height $(97.66 \mathrm{~cm})$ was recorded in BRRI dhan33 with control treatment (Table 3). The highest number of total tillers hill ${ }^{-1}$ (12.81) was found in BRRI dhan46 with 2 pellets of USG/4 hills providing $60 \mathrm{~kg} \mathrm{~N} \mathrm{ha}^{-1}$ and the lowest number (5.91) was produced by BRRI dhan34 with control treatment (Table 3). Effect of interaction between variety and nitrogen fertilizer application on number of effective tillers hill ${ }^{-1}$ was not significant. However, numerically the highest number of effective tillers hill ${ }^{-1}$ (11.83) was recorded from the treatment combination BRRI dhan46 with 2 pellets of USG/4 hills providing $60 \mathrm{~kg} \mathrm{~N} \mathrm{ha}^{-1}$ and the lowest one (3.50) was recorded in BRRI dhan33 with control treatment (Table 3). The highest number of grains panicle ${ }^{-1}$ (160.99) was found in BRRI dhan46 with two pellets of USG/4 hills providing $60 \mathrm{~kg} \mathrm{~N}^{-1}$ treatment combination and the lowest number (122.71) in BRRI dhan33 with control treatment (Table 3). The highest number of sterile spikelets panicle ${ }^{-1}(28.58)$ was obtained in BRRI dhan33 with control treatment. The lowest number (11.13) was obtained in BRRI dhan46 with two pellets of USG/4 hills providing $60 \mathrm{~kg} \mathrm{~N} \mathrm{ha}^{-1}$ (Table 3). Weight of 1000 grains, grain yield and straw yield were not significantly affected by the interaction between variety and level of nitrogen application. However, numerically the highest grain yield $\left(5.61 \mathrm{t} \mathrm{ha}^{-1}\right)$ was obtained in BRRI dhan46 with two pellets of USG/4 hills providing $60 \mathrm{~kg} \mathrm{~N} \mathrm{ha}^{-1}$. The lowest grain yield $\left(2.88 \mathrm{t} \mathrm{ha}^{-1}\right)$ was obtained from BRRI dhan33 with control treatment (Table 2).

The highest biological yield $\left(12.58 \mathrm{t} \mathrm{ha}^{-1}\right)$ was recorded from BRRI dhan46 with two pellets of USG/4 hills providing $60 \mathrm{~kg} \mathrm{~N} \mathrm{ha}^{-1}$ treatment combination and the lowest straw yield $\left(4.88 \mathrm{t} \mathrm{ha}^{-1}\right)$ was obtained in BRRI dhan33 with control treatment (Table 3). The highest harvest index $(44.60 \%)$ was obtained in BRRI dhan46 with two pellets of USG/4 hills providing $60 \mathrm{~kg} \mathrm{~N}^{-1}$ treatment combination. The lowest one $(37.67 \%)$ was obtained in BRRI dhan33 with control treatment (Table 3).

From this study, it can be concluded that performance of BRRI dhan46 was better over other tested varieties. Two pellets of USG $\left(0.9 \mathrm{~g}\right.$ each) $/ 4$ hills applied at 25 and 45 DAT providing $60 \mathrm{~kg} \mathrm{~N}^{-1} \mathrm{was}^{-1}$ we optimum level of nitrogen in respect of grain and straw yield. 
Table 3. Effect of interaction of variety and nitrogen level on crop characters, components and yield of transplant Aman rice

\begin{tabular}{|c|c|c|c|c|c|c|c|c|c|c|c|c|}
\hline $\begin{array}{l}\text { Interaction } \\
(V \times N)\end{array}$ & $\begin{array}{l}\text { Plant } \\
\text { height } \\
(\mathrm{cm})\end{array}$ & \begin{tabular}{|c|} 
Total \\
tillers hill-1 \\
(no.)
\end{tabular} & \begin{tabular}{|c|} 
Effective \\
tillers hill-1 \\
(no.)
\end{tabular} & $\begin{array}{c}\text { Non-effective } \\
\text { tillers } \\
\text { hill-1 }^{-1} \text { (no.) }\end{array}$ & \begin{tabular}{|l|} 
Panicle \\
length \\
$(\mathrm{cm})$ \\
\end{tabular} & $\begin{array}{c}\text { Grains } \\
\text { penicle-1 } \\
\text { (no.) }\end{array}$ & $\begin{array}{c}\text { Sterile } \\
\text { spikelets } \\
\text { penicle-1 }^{-1} \text { (no.) }\end{array}$ & $\begin{array}{c}\text { 1000-grain } \\
\text { weight } \\
\text { (g) }\end{array}$ & $\begin{array}{c}\text { Grain } \\
\text { yield } \\
\left(\mathrm{t} \mathrm{ha}^{-1}\right)\end{array}$ & $\begin{array}{c}\text { Straw } \\
\text { yield } \\
\left(\mathrm{t} \mathrm{ha}^{-1}\right)\end{array}$ & $\begin{array}{c}\text { Biological } \\
\text { yield } \\
\left.\left(\mathrm{t} \mathrm{ha}^{-1}\right)\right)\end{array}$ & $\begin{array}{c}\text { Harvest } \\
\text { index } \\
(\%)\end{array}$ \\
\hline $\mathrm{V}_{1} \times \mathrm{N}_{0}$ & 97.66 & $6.79 \mathrm{~g}$ & $3.50 \mathrm{i}$ & $3.30 \mathrm{a}$ & 21.80 & $122.71 \mathrm{~g}$ & $28.56 \mathrm{~b}$ & 23.32 & $2.88 \mathrm{~h}$ & 5.67 & $8.24 \mathrm{def}$ & 37.67ab \\
\hline$V_{1} \times N_{1}$ & 100.02 & $9.68 \mathrm{e}$ & $7.38 \mathrm{fg}$ & $2.30 \mathrm{bc}$ & 20.37 & $132.72 f$ & $22.74 \mathrm{de}$ & 23.00 & 4.38ef & 4.88 & $10.02 \mathrm{~g}$ & $39.14 \mathrm{~h}$ \\
\hline$V_{1} \times N_{2}$ & 102.58 & $11.26 \mathrm{bc}$ & $9.19 \mathrm{~cd}$ & $2.07 \mathrm{bcd}$ & 20.73 & $125.60 \mathrm{~g}$ & $20.48 \mathrm{ef}$ & 22.90 & 4.53def & 5.50 & $9.80 f$ & 43.90a-e \\
\hline $\mathrm{V}_{1} \times \mathrm{N}_{3}$ & 103.60 & $11.81 \mathrm{ab}$ & $10.13 \mathrm{bc}$ & $1.67 \mathrm{~b}-\mathrm{e}$ & 20.57 & 142.18bcd & $17.17 \mathrm{gh}$ & 22.80 & $4.87 \mathrm{~cd}$ & 6.57 & $11.44 \mathrm{~b}$ & 42.61c-g \\
\hline $\mathrm{V}_{2} \times \mathrm{N}_{0}$ & 123.97 & $5.91 \mathrm{~g}$ & $3.76 \mathrm{i}$ & $2.16 \mathrm{bc}$ & 21.93 & 135.13ef & $31.77 \mathrm{a}$ & 23.43 & $3.26 \mathrm{~g}$ & 6.33 & $11.16 \mathrm{~b}$ & 43.27a-f \\
\hline $\mathrm{V}_{2} \times \mathrm{N}_{1}$ & 124.79 & $10.71 \mathrm{~b}-\mathrm{e}$ & 8.69de & $2.02 \mathrm{bcd}$ & 19.80 & $145.95 b c$ & $20.74 \mathrm{ef}$ & 22.77 & $4.33 \mathrm{f}$ & 5.78 & 10.11def & $42.81 \mathrm{~b}-\mathrm{g}$ \\
\hline $\mathrm{V}_{2} \times \mathrm{N}_{2}$ & 122.75 & 11.19bcd & $10.00 \mathrm{bc}$ & 1.19def & 22.00 & $147.69 \mathrm{~b}$ & $17.28 \mathrm{gh}$ & 23.56 & 4.37ef & 6.47 & $10.96 \mathrm{bc}$ & $40.93 \mathrm{~g}$ \\
\hline $\mathrm{V}_{2} \times \mathrm{N}_{3}$ & 125.68 & $12.52 \mathrm{a}$ & $10.78 \mathrm{ab}$ & $1.74 \mathrm{~b}-\mathrm{e}$ & 21.33 & $157.17 a$ & 14.90hi & 22.76 & $5.13 b c$ & 7.11 & $12.24 a$ & 41.91efg \\
\hline $\mathrm{V}_{3} \times \mathrm{N}_{0}$ & 109.13 & $6.38 \mathrm{~g}$ & $3.75 \mathrm{i}$ & $2.63 a b$ & 21.27 & 137.28def & $25.03 \mathrm{~cd}$ & 23.51 & $3.20 \mathrm{gh}$ & 6.00 & 10.43de & $42.60 \mathrm{c}-\mathrm{g}$ \\
\hline $\mathrm{V}_{3} \times \mathrm{N}_{1}$ & 111.69 & $8.04 f$ & $5.74 \mathrm{~h}$ & $2.30 \mathrm{bc}$ & 20.37 & $132.61 \mathrm{f}$ & 22.14def & 23.53 & 4.35ef & 5.80 & 9.92ef & $41.56 f g$ \\
\hline $\mathrm{V}_{3} \times \mathrm{N}_{2}$ & 111.31 & 10.03cde & 7.93ef & $2.10 \mathrm{bcd}$ & 20.77 & $132.26 f$ & $19.32 \mathrm{fg}$ & 23.36 & 4.61def & 6.08 & $10.47 \mathrm{~cd}$ & 41.89efg \\
\hline $\mathrm{V}_{3} \times \mathrm{N}_{3}$ & 112.16 & $11.23 b c$ & $9.77 \mathrm{bcd}$ & $1.46 \mathrm{cde}$ & 22.10 & $160.65 a$ & $14.03 i j$ & 23.14 & 5.35ab & 7.06 & $12.27 \mathrm{a}$ & $42.51 \mathrm{~d}-\mathrm{g}$ \\
\hline $\mathrm{V}_{4} \times \mathrm{N}_{0}$ & 103.37 & $5.63 \mathrm{~g}$ & $3.71 \mathrm{i}$ & $1.93 \mathrm{bcd}$ & 22.13 & 140.20cde & $26.31 \mathrm{bc}$ & 23.67 & 3.09gh & 6.21 & $11.14 \mathrm{~b}$ & 44.30a-d \\
\hline $\mathrm{V}_{4} \times \mathrm{N}_{1}$ & 104.79 & 9.95de & $6.48 \mathrm{gh}$ & $3.47 a$ & 21.33 & $133.17 f$ & $24.24 \mathrm{~cd}$ & 23.02 & 4.72de & 5.75 & $10.49 \mathrm{~cd}$ & $45.20 \mathrm{a}$ \\
\hline $\mathrm{V}_{4} \times \mathrm{N}_{2}$ & 108.33 & $11.29 \mathrm{bc}$ & $10.73 \mathrm{ab}$ & $0.55 f$ & 21.73 & $143.57 \mathrm{bc}$ & 20.23efg & 23.38 & $4.80 \mathrm{~cd}$ & 6.23 & $11.13 \mathrm{~b}$ & 43.98a-d \\
\hline $\mathrm{V}_{4} \times \mathrm{N}_{3}$ & 110.82 & $12.81 \mathrm{a}$ & $11.83 a$ & 0 off & 20.07 & $160.99 a$ & $11.13 \mathrm{j}$ & 23.31 & $5.61 \mathrm{a}$ & 6.97 & $12.58 \mathrm{a}$ & 44.60abc \\
\hline $\mathrm{CV}(\%)$ & 4.0 & 7.14 & 9.19 & 12.82 & 6.23 & 3.4 & 8.32 & 3.47 & 4.58 & 4.2 & 3.65 & 3.50 \\
\hline Level of sig. & NS & $\star \star *$ & $* *$ & ** & NS & $\star \star *$ & $\star \star *$ & NS & $\star *$ & NS & ** & 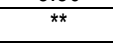 \\
\hline
\end{tabular}

In a column, figures with same letter or without letter do not differ significantly whereas figures with dissimilar letters differ significantly as per DMRT

NS $=$ Not significant ${ }^{* *}=$ Significant at $1 \%$ level of probability

$\mathrm{V}_{1}=\mathrm{BRRI}$ dhan $33, \mathrm{~V}_{2}=\mathrm{BRRI}$ dhan34, $\mathrm{V}_{3}=\mathrm{BRRI}$ dhan39 and $\mathrm{V}_{4}=\mathrm{BRRI}$ dhan 46

$\mathrm{N}_{0}=$ Control, $\mathrm{N}_{1}$ = Prilled urea $\left(50 \mathrm{~kg} \mathrm{~N}\right.$ ha $\left.{ }^{-1}\right), \mathrm{N}_{2}=$ One pellet $(0.9 \mathrm{~g})$ of USG $/ 4$ hills of two adjacent rows [applied at 10 DAT], $\mathrm{N}_{3}=$

Two pellets ( $0.9 \mathrm{~g}$ each) of USG $/ 4$ hills of two adjacent rows [One pellet was applied at 10 DAT and another one at 45 DAT

\section{References}

Alam, B.M.R. 2002. Effect of different levels of urea super granule on the growth and yield of three varieties of boro rice. MS (Ag.) Thesis, Dept. Agron., Bangladesh Agril. Univ., Mymensingh. 111 p.

BBS (Bangladesh Bureau of Statistics). 2011. Statistical Year Book of Bangladesh. Stat. Div., Minis. Plan., Govt. People's Repub. of Bangladesh, Dhaka. pp.136-140.

Bhowmick, N. and Nayak, R.L. 2000. Response of hybrid rice (Oryza sativa) varities to nitrogen, phosphorus and potassium fertilizers during dry (boro) season in West Bengal. Indian J. Agron. 45(2): 323-326.

BRRI (Bangladesh Rice Research Institute). 1991. Annual Report for 1990. Bangladesh Rice Res. Inst., Joydebpur, Gazipur. pp. 5-13.

Chowdhury, M.J.U., Sarker, A.U., Sarkar, M.A.R. and Kashem, M.A. 1993. Effect of variety and number of seedlings hill ${ }^{-1}$ on the yield and its components on late transplanted aman rice. Bangladesh J. Agril. Sci. 20(2): 311-316.

Fatema-Tuz-Zohra, Ali, R., salim, M. and Kader, M.A. 2013. Effect of urea super granules on the performance of transplant aman rice. J. Agrofor. Environ. 7 (1): 49-52.

Gomez, K.A, and Gomez, A.A. 1984. Statistical Procedures for Agricultural Research. Intl. Rice Res. Inst., John Wiley and Sons. New York, Chickester, Brisbane, Toronto, Singapore, p. 680.

Hossain, M.A., Salahuddin, A.B.M., Ray, S.K., Nasreen, S. and Ali, M.A. 1995. Effect of green manuring on the growth and yield of transplant aman rice. Bangladesh J. Agril. Sci. 22(1): 21-29.

Niu, I., Li, Y., Zhang, W., Niu, Z. and Zhou, M. 2001. High yielding and good quality Tianjin 1244. Japonica hybrid cultivar series. Intl. Rice Res. Notes. 26(1): 12. 
Novoa, R. and Loomis, R. S. 1981. Nitrogen and plant production. Plant and Soil. 58: 177-204.

Nuruzzaman, M., Yamamoto, Y., Nitta, Y., Yoshida, T. and Miyazaki, A. 2000. Varietal differences in tillering ability of fourteen Japonica and Indica rice varieties. Soil Sci. Plant Nutri. 46(2): 381-391.

Prodhan, S.B. 1992. "Status of fertilizer use in developing countries of Asia and the Pacific region": Proc. Regi. FADINAP seminar, Chiang Mai, Thailand. pp. 37-47.

Singh, B.K. and Singh, R.P. 1986. Effect of modified urea materials on rainfed low land transplanted rice and their residual effect on succeeding wheat crop. Indian J. Agron. 31(2): 198-200.

Tyeb, A., Paul, S.K. and Samad, M.A. 2013. Performance of variety and spacing on the yield and yield contributing characters of transplanted aman rice. J. Agrofor. Environ. 24:103-108. 